\title{
Effect Judicial Independence on the Foreign Direct Investment in South and South-East Asian Countries
}

Faruque Mohammadf ( $\square$ faruque.mohammad@emle.eu )

Supreme Court of Bangladesh https://orcid.org/0000-0002-9518-6199

Original Research

Keywords: Judicial Independence, Foreign Direct Investment, Property Rights, Economic Growth

Posted Date: February 9th, 2021

DOl: https://doi.org/10.21203/rs.3.rs-171730/v1

License: (c) (1) This work is licensed under a Creative Commons Attribution 4.0 International License.

Read Full License 


\title{
Effect Judicial Independence on the Foreign Direct Investment in South and South- East Asian Countries
}

\begin{abstract}
:
Judicial Independence is one of the most important characterstics of quality and well functioning judiciary. Efficient and independent courts play crucial role to enforce contract and property rights efficiently and impartially, ensure individual liberty and create favorable environment for domestic as well as foreign investment and facilitate the economic development. It is proved that de facto judicial independence has a robust highly significant impact on economic growth. Foreign Direct Investment, a source of capital and an element of globalization plays an important role in the economic development of the countries. It is one of important source of capital which stimulate domestic investment, creates new employment and expedites the transfer of technology. The objective of this study is to examine whether judicial independence has an impact to attract foreign direct investment in south and south-east asia region.
\end{abstract}

Key Words: Judicial Independence, Foreign Direct Investment, Property Rights, Economic Growth

JEL Classification: K400 


\section{Introduction:}

South and South-East Asian countries, mostly developing countries of the world have keen interests to attract Foreign Direct Investment (FDI) since these countries do not have adequate capital for investments. There has been a growing interest in the determinants of foreign direct investment (FDI) in developing countries, as FDI is considered one of the most stable components of capital inflows to developing countries and can also be a vehicle for technological progress through the use and dissemination of improved production techniques.(Quéré, Coupet, Mayer). Not surprisingly, thus, a number of authors have also studied the link between institutions and FDI. Such a link could be seen as one channel through which institutions promote productivity growth. Indeed, good institutions are supposed to exert their positive influence on development through the promotion of investment in general, which faces less uncertainty and higher expected rates of return. Because FDI is now a very large share of capital formation in poor countries (UNCTAD, 2004), the FDI-promoting effect of good institutions might be an important channel of their overall effect on growth and development. Understading the determinants of foreign direct investment is very crucial because there is immense growth of foreign direct investment in the developing world over the last twenty years which is around \$334 billion in 2005( UNCTAD 2006 Report).

This study answers the questions such as i) what are the determinants that help to attract foreign direct investment in the developing countries particularly in South Asian and South- 
East Asian countries? And ii) Does the Judicial Independence, an institutional determinant has impact on foreign direct investment in this region?

This paper is organized as follows: Section II reviews the previous studies e.g literature about the determinants of foreign direct investment, Section III deals with the data and methodology, Setion IV provides empirical results and Section V presents the conclusion of this study.

\section{Inward Foreign Direct Investment and South Asia:}

South Asia is consists of 8 countries i.e. Afganistan, Bangladesh, Bhutan, India, Nepal, Maldives, Pakistan and Srilanka having about 1.94 billions people represent 24 percent of world population.Inflows of foreign direct investment have increased gradually in South Asian countries over the years since 1990. However, the share of inward foreign direct investment of this region in terms of global foreign direct investment inflow is very insignificant. The inflows of FDI as a percentage of Gross Domestic Product of South Asian countries are the lowest among all the developing countries of the world which is less than two percent on average in the period of 2000-2010, although South Asia have average 6.7 percent annual increase in real GDP over the last decade. The economy of South Asia is twice larger than that of Sub-Saharan Africa but average annual inward FDI inflow of SubSaharan Africa's is US\$ 19.4 billion which is bigger than that of (18.3 billion US \$) South Asia. About $70 \%$ of inward FDI of South Asia came from developed countries in the period between 2003 to 2011 that includes 32\% from European Union countries, 17\% from the US and $20 \%$ from other advanced economies of the world such OECD countries. The lion shares of inward FDI of South Asian region came from the Middle East and North Africa 
(MENA) and the East Asia and Pacific regions. A small portion of total inward FDI i.e 5 percent of inward FDI arrived within the region.

\section{Trend of FDI in South Asia Region:}

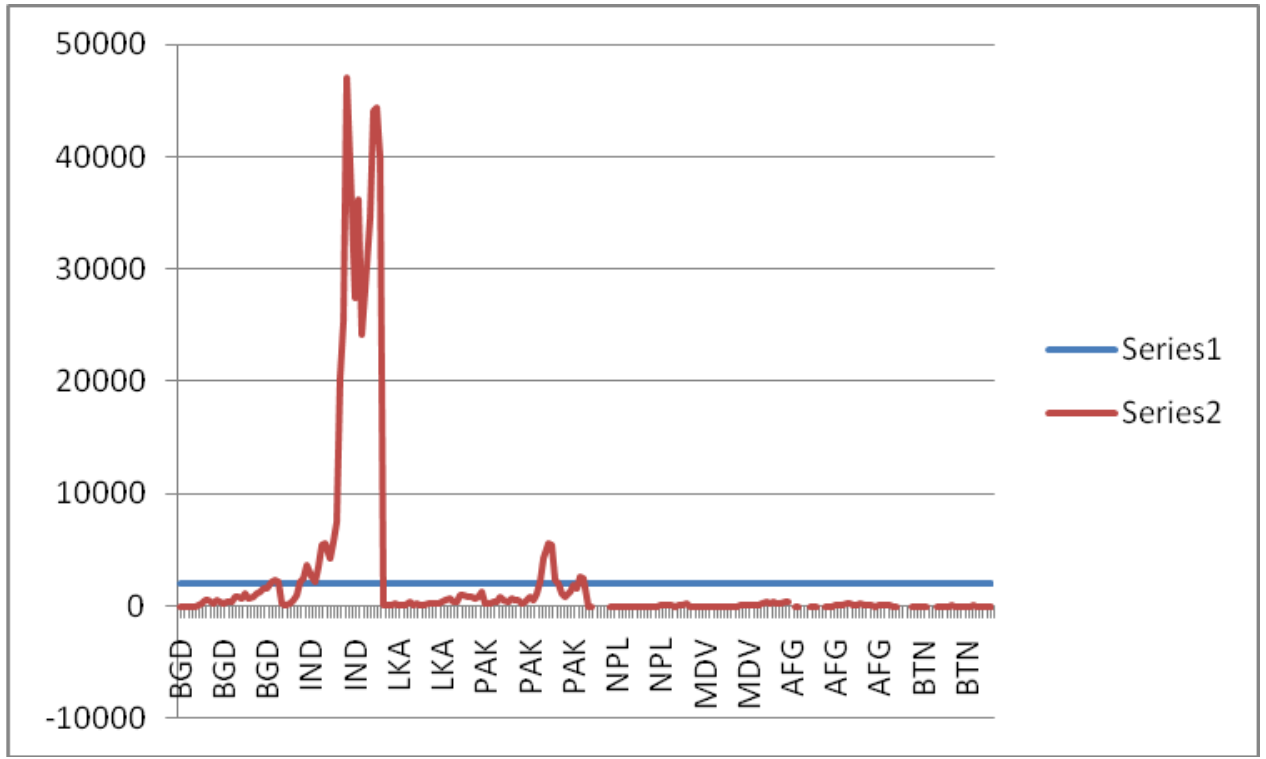

\section{Inward FDI and South East Asia:}

Foreign direct investments have played great contribution to the economic development of Southeast Asian countries. But the two economic recessions in 1997 and 2007 have significant impact on the foreign direct investments inflows in Southeast Asia. Each country of this region experienced a different level of shock in terms of inflow of FDI.

Southeast Asia is one of the most successful emerging economic regions of the world with regard to export-led development through attracting FDI. FDI inflows as a percentage of Gross Domestic Product (GDP) over the last five years have been at record level for many countries of this region Southeast Asia, having 669.21 millions people in 11 countries and 
members of the Association Nations (ASEAN) have attracted the largest share of intraregional greenfield investments which is $\$ 100$ billion in 2018. Foreign Direct Investment to South-East Asia has increased to a record level from $\$ 123$ billion in 2016 to $\$ 137$ billion in 2017.The share of FDI inflow of ASEAN to developing economies rose from $18 \%$ in the year 2016 to 20 percent in 2017. Although Global Foreign Direct Investment flows declined for the $3^{\text {rd }}$ consecutive year in 2018, Asia-Pacific region received the largest share of global FDI inflows, attracting 45 percent in 2018 compared with 39 percent in 2017. FDI inflows to South-East Asia, which includes members of ASEAN as well as Timor-Leste, grew by 3 percent in 2018 to $\$ 149$ billion.

The global financial crisis in 2008 caused a negative effect on inward foreign direct investment into Southeast Asian countries. FDI inflow decreased sharply from $\$ 74.39$ billion in 2007 to $\$ 49.49$ billion in 2008 and continues fall to $\$ 39.62$ billioin 2009 .

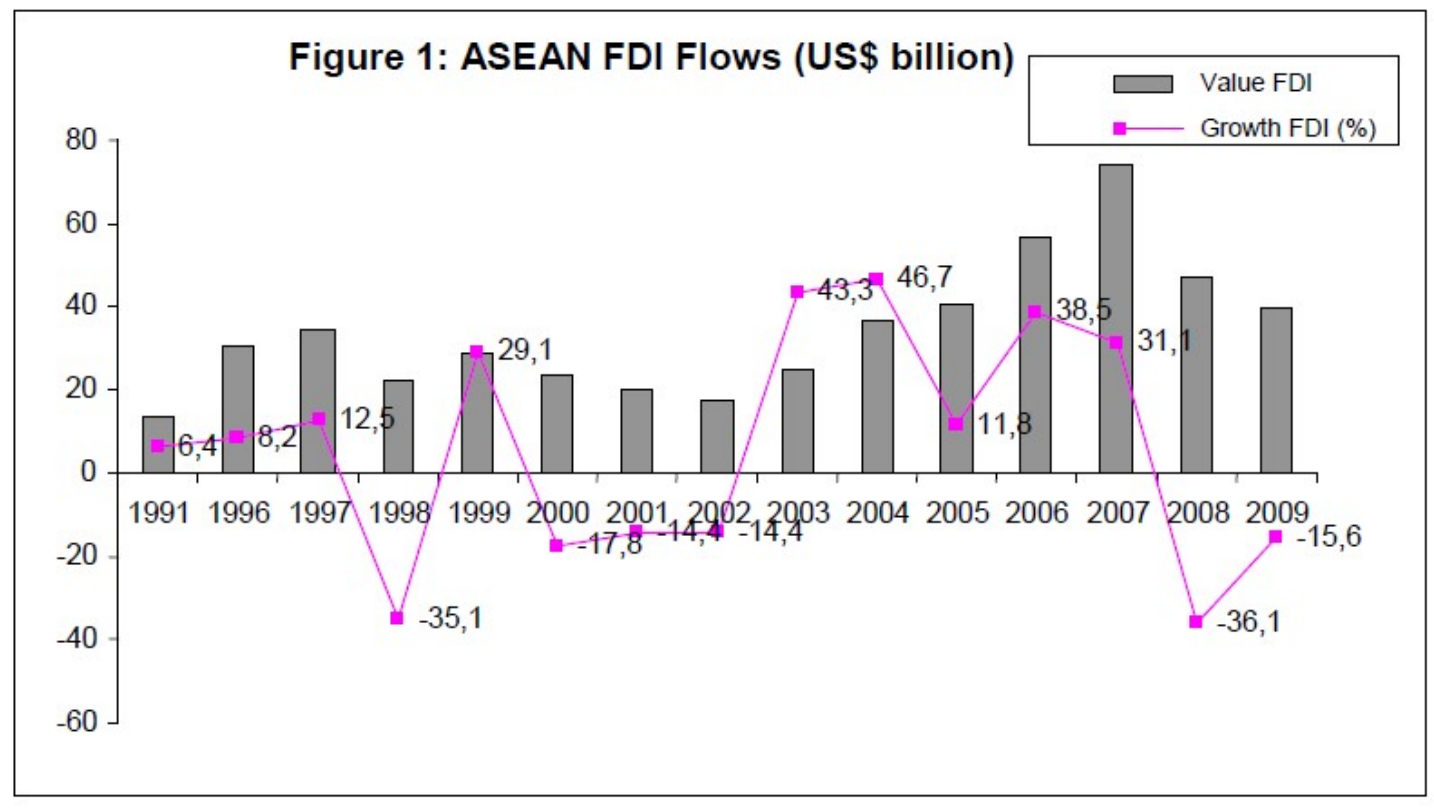

Source: UNCTAD Stat. 


\section{Share of FDI among the Southeast Asian countries:}

The inflows of FDI among the Southeast Asian countries are uneven. Singapore attracted the largest portion of FDI which is $\$ 349.6$ billion represents 50 percent of total FDI inflows in this region. In 2009 the stock of FDI came to the 6 Southeast Asian countries valuing $\$ 666.47$ billion. The share of the FDI inflows of other countries of this region are Thailand $\$ 99$ billion, Indonesia $\$ 73$ billion, Malaysia $\$ 75$ billion, Vietnam $\$ 53$ billion, Philippines \$24 billion. Lao PDR received an small portion of FDI.

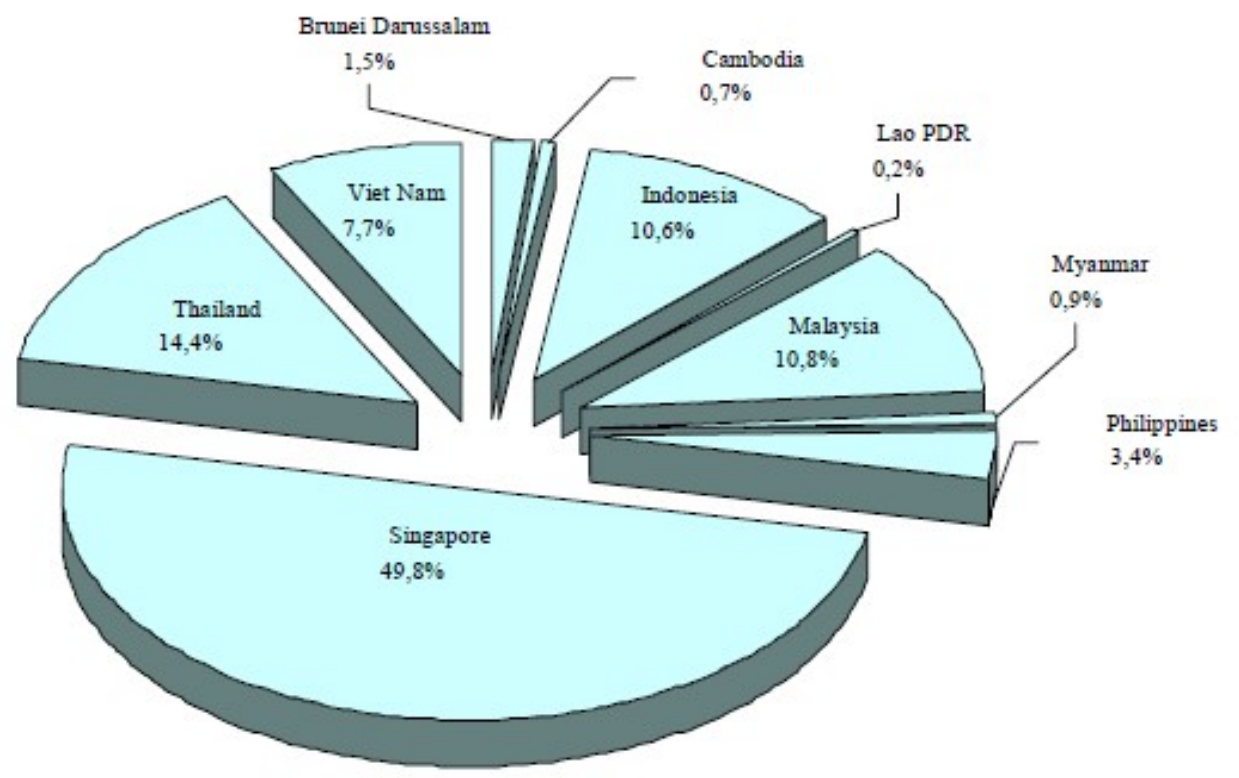

Ref: UNCTAD 
FDI inflow trend in South East Asia(1990-2017)

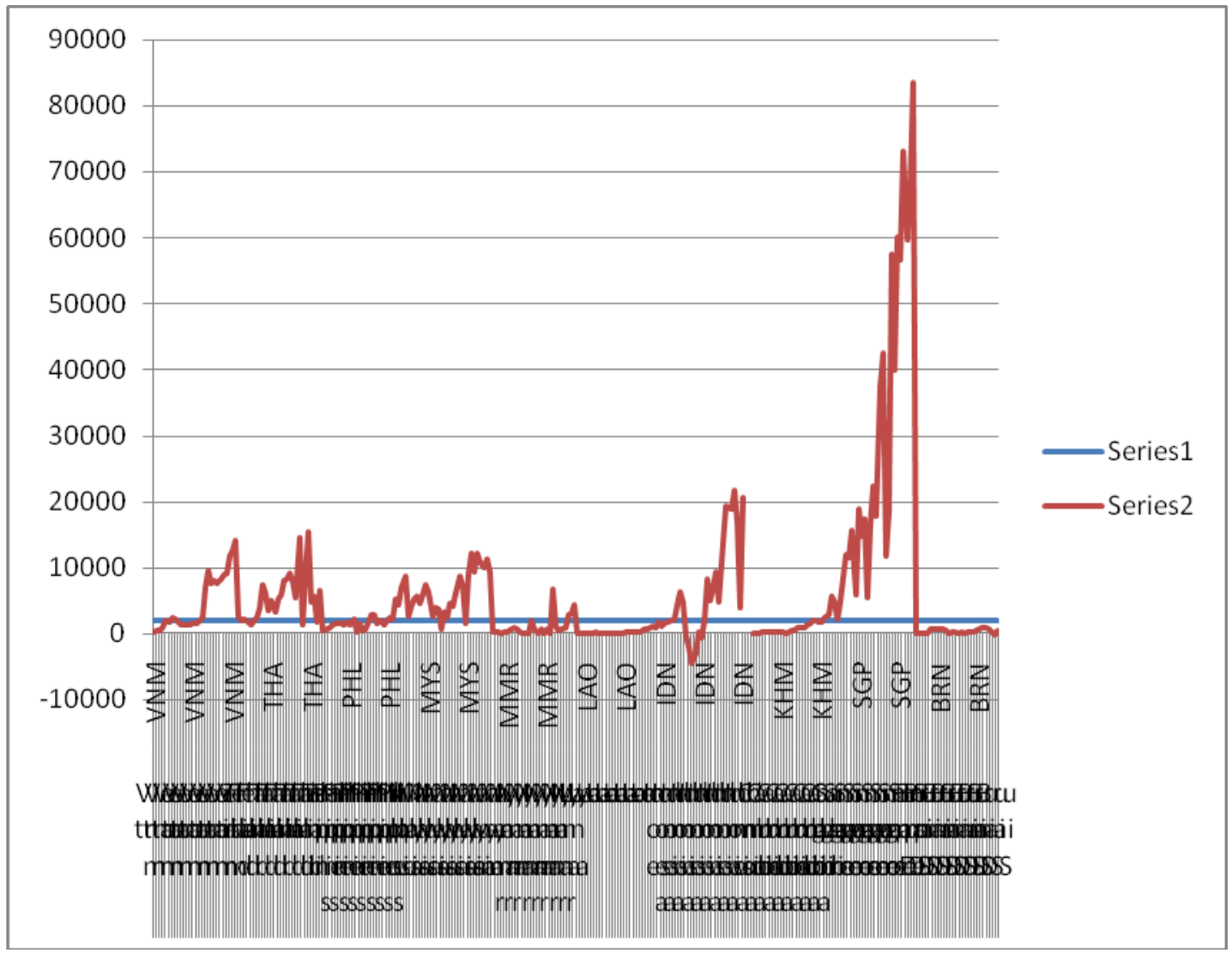




\section{Importance of Judicial Independence:}

Judicial Independence implies that judges can perform their duties as per law free from influence or coercion, control by other actors whether government or private. Judicial Independence is crucial when three scenarios occure such as-

i) Dispute between citizens or private actors: Impartial and independent judiciary can enforce contracts impartially and thereby reduce transaction costs. Lower transaction costs maximize welfare enhancing transactions.

ii) Dispute between government actors: conflict between the government actors may occur and lead to power game in the absence of an independent and impartial organ. An independent court may help them to play their role as per law provided by the constitution.

iii) Dispute between the Government and Citizen: Independent Judiciary protect the rights of the citizens provided by the constitution. It prevents excutive and legislative encroachment upon those rights. It helps to establish rule of law and ensure good governance, an institutional determinants to attract FDI. It protects the property rights of the citizens from expropriation. Judges can review the constitutionality of the newly passed law. It can also ascertain whether government branch are performing their function with regard to citizen's rights by following due process of law. 


\section{Related Literature :}

Analysis of Panel data and US CEO's Survey indicates that rule of law and judicial strength are linked to FDI inflows in Latin American countries (Staats and Biglaiser,2012). Institutional quality has a positive and significant effect on FDI and matters to FDI ( Buchanan at el). Blonigen and Wang (2005) argue that countries that attract strong FDI flows typically have a host of favorable policies-for example, strong property-rights protection, stable macro policies, adequate infrastructure, and a clear and competitive regulatory environment - which can crowd-in domestic investment and improve overall productivity. Empirical literature on the institutional quality and economic growth has also shows a positive link between the quality of institutions and economic growth in a society

( Acemoglu and Verdier,1998). Ali and Fiess concludes that institutional quality exerts a significant role in determining FDI inflows.

Institutional determinants such as political risks factors, the functioning of bureaucracy, corruption and judicial system have considerable impact on the American Firms investing abroad ( Wheeler \& Mody,1992). Foreign investments face expropriation risks where protection of property rights are very weak and poor (Henisz, 2000; Henisz \& Williamson,1999). Compliance with contracts, protection for property rights, and economic freedom are important determinants to attract more foreign investment (Kapuria-Foreman, 2007). Production as well as transaction costs can be reduced by good institutions (North 1990). An inefficient legal system increases transaction costs by failing to provide cheap mechanism for enforcing legal rights and obligations( Coase,1988). De jure judicial independence does not have a clear impact on economic growth but de facto judicial independence positively influences real GDP growth per capita ( Feld \& Voigt,2003). 
Reisen and Soto(2001) indicate that foreign direct investment and foreign portfolio investment may increase economic growth. Basu and Guariglia (2007) found positive link between foreign direct investment and economic growth in 119 countries of the world . Inefficient institutions as measured by corruption and weak enforcement of contracts deter foreign investment (Gastanaga et al., 1998; Campos et al.1999; Asiedu and Villamil, 2000; and Wei 2000). Elizabeth Asiedu concludes that large local markets, natural resource endowments, good infrastructure, low inflation, an efficient legal system and a good investment framework promote FDI. Economic theory suggests that effective, independent courts promote investment and economic growth. (Klerman,2007). In most developed countries, constitutional guarantees and powerful courts reduce the risk of expropriation (North,1990). Tajul\& Hussin(2010) indicates that improvement in the institutional quality is also a crucial determinant to attract new FDI flows into the South East Asian region as a part of future policy strategy. Bulent Dogru indicates that Judicial independence increases the FDI inflows to Eastern Europe and South Asia. GDP per capita, GDP, Deposit interest rate and trade openness are the main determinants of inward FDI to host country.IMF working paper concludes that better infrastructure and a more independent judiciary attract more tertiary FDI. Mihaela Peres et al indicate that control of corruption and rule of law are important determinants in attracting FDI inflows in both developed and developing countries. Hoang finds that the market size, openness of the economy, quality infrastructure, human capital, labor productivity are the main factors that have a positive impact on FDI flows. Moreover,exchange rate policy, real interest rates, political risk and institutional quality also affect FDI inflows. Henisz and Williamson (1999) and Henisz emphasize that foreign investors face two kinds of risks in case of poor property right 
protection in the host country such as a host country's government expropriate return of FDI or nationalize them and local competitors may persuade the government to favor them policy support due to better access to the political processs at the cost ot foreign investors,

\section{Data and Methodology:}

Data on Foreign Direct Investment of 8 South Asian and 10 South-East Asian countries total 18 Countries of these region for the period of 1990-2017 (28 years data) are collected from the database of the United Nations Commission for Trade and Development (UNCTAD). Data on macroeconomic variables relating to determinants of foreign direct investment such as Expenditure side real GDP at chained PPPs( rgdpe), population as a proxy to market size of the host countries, Human Capital Index (HC) based on years of schooling and return to education are taken from Penn World Table version 9.0, Trade as percentage of GDP from World Development Indicator of World Bank's Data and Latent Judicial Independence (LJI) scores from Linzer and Staton (2015)'s “ A Global Measure of Judicial Independence and GDP per capita from World Development Indicator (WDI). The following variables are taken into consideration on the basis of previous empirical literature regarding the determinants of Foreign Direct Investment in this region.

FDI $=\mathrm{f}\{$ latent Judicial Independence, Trade openness, Real GDP, Population, Human Capital, GDP per capita,Protection of Property Rights\}

$F D I=\alpha+a_{1} L J I+a_{2}$ trade $+a_{3} r g d p e+a_{4} p o p+a_{5} h c+a_{5} g d p p c+a_{6} p p r+e$ 
Variable considered for analysis:

\begin{tabular}{|l|l|}
\hline \multicolumn{1}{|c|}{ FDI inflows } & \multicolumn{1}{c|}{ Dependent Variable } \\
\hline Latent Judicial Independence & Judicial Independenc Indicator used in Linzer \& Staton(2015) \\
\hline Trade Openness (Trade (\% of GDP) & Trade is the sum of exports and imports of goods and services \\
& measured as a share of gross domestic product. \\
\hline RGDPe & Expenditure side real GDP at chained PPPs( rgdpe) \\
\hline Population & Population \\
\hline Human Capital & Based on Years of Schooling \& return to Education \\
\hline GDPPC & GDP per capita to measure the Markent prospects \\
\hline PPR & Protection of Propety Rights \\
\hline
\end{tabular}

\section{Foreign Direct Investment}

Foreign direct investment (FDI) is considered as the dependent variable in the model, measured by net inflows of foreign direct investment since we want to know the effect of Judicial Independence and other macro economic and institutional variables on the foreign direct investment of the South and South-East Asian region.

\section{Market size:}

The aim of FDI in emerging developing countries is to tap the domestic market, and thus market size does matter for domestic market oriented FDI. Market size is generally measured by GDP, per capita income or size of the middle class. The size of the market or per capita income are indicators of the sophistication and breath of the domestic market. 
Thus, an economy with a large market size (along with other factors) should attract more FDI. Market size is important for FDI as it provides potential for local sales, greater profitability of local sales to export sales and relatively diverseresources, which make local sourcing more feasible (Pfefferman and Madarassy 1992). Thus, a large market size provides more opportunities for sales and also profits to foreign firms, and therefore attracts FDI (Wang and Swain, 1995: Moore, 1993; Schneider and Frey, 1985; Frey, 1984). FDI inflow in any period is a function of market size (Wang and Swain,1995).

\section{Human capital:}

The availability of a cheap workforce, particularly an educated one,influences investment decisions and thus is one of the determinants of FDI inflow. In this study, human capital is calculated on the basif of years of schooling \& return to education.

\section{GDP Per Capita:}

Since Foreign Direct Investment is used in domestic production, it is added to GDP. It helps to measure the market prospect of the host country.

\section{Expenditure side real GDP at chained PPPs( rgdpe):}

Expenditure method, a common method to calculate a country's GDP which includes consumer spending, investment, government expenditure and net exports. The real GDP considers inflation. It includes changes in general price level in a given year to provide an accurate picture of an economy's growth using base year prices.

\section{Trade:}

Trade is the sum of exports and imports of goods and services measured as a share of gross domestic product. Trade is one of the important macroeconomic variables to attract Foreign Direct Investment. Torissi (1985) observed that a trade surplus is indicative of a dynamic 
and healthy economy with export potential and thereby more likely to attract foreign direct investment.

\section{Protection of Property Rights:}

Protection of property rights encourage large scale investment in a country. Investor will invest in a country when they feel confident about the property rights. Strong property rights reduce the risks of expropriation. Both physical property rights and intellectual property rights promote investment and nurture economic growth.

\section{Results:}

In table 1 results of simple Ordinary Least Square (OLS) and Panel regrssion with fixed effect as well as well random effect is given.In OLS, the P value of Latent Judicial Independence is significant at 5\% level and t statistics is 1.96 . R-squared is 0.6198 that means the model explained the variation with dependent variable is more than $69 \%$. P value of regression of Protection of Property Rights (PPR) is 0.034 which is significant at 5\% level.P value of trade is 0.000 which is significant at $1 \%$ level and t statistics is 8.59 . The $\mathrm{P}$ value of real gdp by expenditure is 0.000 which appears to be significant at $1 \%$ confidence level and t statistics is 11.34 and $\mathrm{F}$ statistics is 0.000 .

Data of 18 South and Southeast asian countries from 1990-2017 is taken for panel regression. In panel regression with fixed effect model, it is observed that $p$ value of LJI is 0.027 which is significant at $5 \%$ level and $t$ statistics is 2.23 and $\mathrm{P}$ value of another variable named protection of property rights is 0.010 and t statistics is 2.59 which appears to be significant at $1 \%$ level. 
Panel data is also regressed with random effect. In random effect, $P$ value of latent judicial independence and protection of property rights is 0.050 and 0.033 respectively and $\mathrm{P}$ value of both variables is significant at 5\% level. The coefficient of judicial independence and protection of property rights both are positive which indicate that judicial independece has positive effect on the foreign direct investment. $\mathrm{P}$ value of trade and rgdpe is 0.000 and 0.000 respectively and both $\mathrm{P}$ value are significant at $1 \%$ confidence level. In sum, the result in table 1 shows that judicial independence has positive and significant effect on foreign direct investment in South and Southeast Asian countries.

Table no:1

\begin{tabular}{|c|c|c|c|}
\hline FDI & OLS & Fe & Re \\
\hline Independent Variables & $0.051^{* *}$ & $0.027^{* *}$ & $(1.96)$ \\
\hline Latent Judicial Independence(LJ) & $(1.96)$ & $(2.23)$ & $0.033^{* *}$ \\
\hline Protection of Property Rights(PPR) & $0.034^{* *}$ & $0.010^{* * *}$ & $(2.13)$ \\
\hline Trade & $(2.13)$ & $(2.59)$ & $\left(8.000^{* * *}\right.$ \\
& $0.000^{* * *}$ & $0.046^{* *}$ & $(-2.01)$ \\
\hline Rgdpe & $(8.59)$ & $0.000^{* * *}$ & $(11.34)$ \\
\hline R-square & $0.000^{* * *}$ & $(8.98)$ & $0.000^{* * *}$ \\
\hline No of Countries & $(11.34)$ & 0.0531 & 18 \\
\hline No of Observations & 0.6198 & 228 & 0.6198 \\
\hline F Statistics & 18 & 0.000 & 230 \\
\hline
\end{tabular}

Note: Dependent variable is Foreign Direct investment (net inflows \% of GDP) from 1990-2017. ***,**,and * statistically significant are the $1 \%, 5 \%$ and $10 \%$ respectively. In parenthesis t statistics is shown. 


\section{Correlation Matrix:}

\begin{tabular}{|l|l|}
\hline \multicolumn{1}{|c|}{ FDI } & \\
\hline LJI & 0.2350 \\
\hline trade & 0.4850 \\
\hline rgdpe & 0.4971 \\
\hline population & 0.3203 \\
\hline hc & 0.4320 \\
\hline gdppc & 0.5629 \\
\hline ppr & 0.5629 \\
\hline
\end{tabular}

\section{Descriptive Statistics}

$\begin{array}{lllllllll} & \text { FDI } & \text { Lji } & \text { trade } & \text { regdpe } & \text { pop } & \text { hc } & \text { gdppc } & \text { ppr } \\ \text { Mean } & 4293.516 & .3739551 & 97.79467 & 471524.9 & 114.782 & 2.063068 & 11570.67 & 5.187863 \\ \text { Min } & 4550.4 & .0205 & .16 & 1038.74 & .223215 & .298 & 293.16 & 1.83 \\ \text { Max } & 83603.9 & .8358 & 437.32 & 8412113 & 1339.18 & 3.974208 & 94940.97 & 9.2 \\ \text { Std. Dev. } & 10297.46 & .2090624 & 80.53412 & 1017535 & 258.9283 & .5542124 & 20133.74 & 1.637922 \\ \text { No of Observation } & 489 & 490 & 450 & 476 & 476 & 456 & 484 & 234 \\ \text { No of Countries } & 18 & 18 & 18 & & 18 & 18 & 18 & 18\end{array}$


FDI and JI in the South \& Southeast Asia:
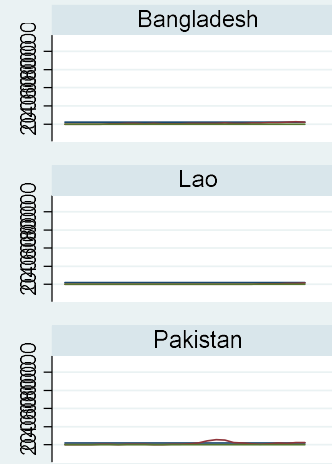

Srilanka
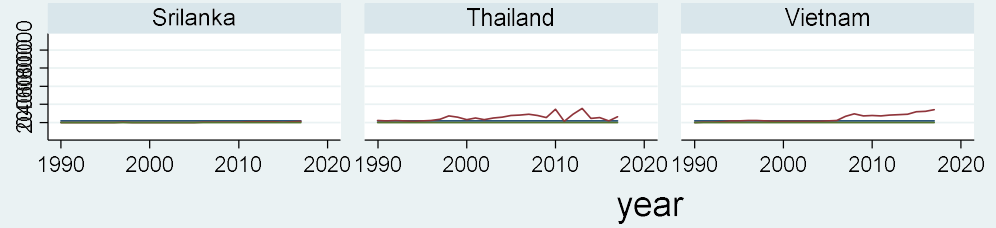

year
India

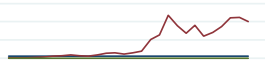

Myanmar

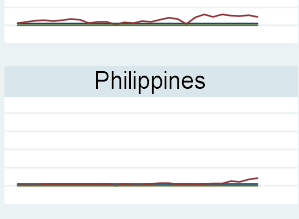

Thailand

Vietnam

fdi

Indonesia

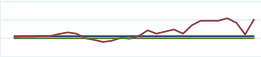

Nepal
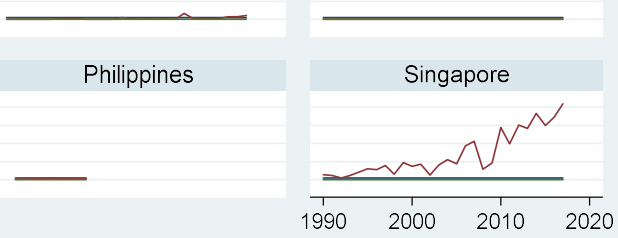

Graphs by country 


\section{Conclusion:}

FDI inflows have close economic integration with the process of globalization and is generally assumed to be a major preceding factor of economic development. On the basis of panel data of 18 countries of South and Southeast Asia Region for 28 years (1990-2017), the association between FDI and Judicial independence has been examined. Econometric result indicates that judicial independence and protection of property rights have positive effect on FDI. The impact of Judicial Independence on the inflow of foreign direct investment in South and Southeast Asia is statistically significant. Judicial independence, an institutional determinant is necessary for rule of law and good governance in a country. The results of this paper supports the view of empirical growth literature that has emphasized the importance of institutions for economic growth. Since judicial independence has effect on foreign direct investment inflows to home countries of South and Southeast Asian countries, policy makers of those countries may feel interest to improve the level of judicial independence. 


\section{Bibliography}

(n.d.).

(n.d.).

(Maxim), L. D. (2014). The foreign direct investments in South-East Asia during the last two decades. Procedia Economics and Finance , $903-908$.

Acemoglu, D. \&. (2005). Unbundling institutions. American Economic Review , 113(5), 949-995.

Agnès Bénassy-Quéré, M. C. (2007). Institutional Determinants of Foreign Direct Investment. The World Economy , 744-782.

Aizenman, J. \&. (2006). Institutional efficiency and the investment share offoreign direct investment. Review of International Economics , 14(4), 683-697.

Ali, F. F. (2010). Do institutions matter for foreign direct investment. Open Economy Review 21 , 201-219.

Biglaiser, J. L. (March 2012). Foreign Direct Investment in Latin America: The importance of Judicial Strength and Rule of Law. International Studies of Quarterly Vol.56 No 1 , 193-202.

Bonnie G. Buchanan, Q. V. (2012). Foreign direct investment and institutional quality:Some empirical evidence. International Review of Financial Review 21 , 81-89.

David M. Gould, C. T. (November 2013). Attracting Foreign Direct Investment:What Can South Asia's Lack of Success Teach Other Developing Countries? Policy Research Working Paper 6696, World Bank,South Asian Region .

Feenstra, R. C. (2015). The Next Generation of the Penn World Table. American Economic Review, 105(10), 3150-3182.

Feld, L. P., \& Voigt, S. (2003). Economic Growth and Judicial Independence: Cross Country Evidence Using a New Set of Indicators. CESifo Working Paper No. 906, Center for Economic Studies and Ifo Institute (CESifo), Munich .

Globerman, S. \&. (n.d.). Global foreign direct investment flows: The role of governance infrastructure. World Development, 30(11), 1899-1919. 30(11), 1899-1919.

Klerman, D. M. (2007). Legal Infrastructure, Judicial Independence, and Economic Development. Krishna Chaitanya Vadlamannati, A. T. (2009). Determinants of foreign direct investment and volatility in South East Asian economies. Journal of the Asia Pacific Economy , 246-261, DOI: 10.1080/13547860902975010.

Lee, Y. (n.d.). The Effect of Judicial Independence on Foreign Direct Investment and Investment Arbitration Laws. 
Mihaela Peres, W. A. (2018). The impact of institutional quality on foreign, direct investment inflows: evidence for developed and developing countries. Economic Research-Ekonomska Istraživanja,SSN: 1331-677X (Print) 1848-9664 (Online) Journal homepage:

http://www.tandfonline.com/loi/rero20, 626-644.

OECD Secretariat. (2019). OECD Investment Policy Reviews: South East Asia. Paris: OECD www.oecd.org/investment/oecd-investment-policy-review-southeast-asia.htm.

Office of Chief Economist, World Bank Group. (2013 Report No: ACS4862). Trends and Determinants of Foreign Direct Investment in South Asia. Washington DC: Office of the Chief Economist, South Asia Region.

Perry, A. (2000). An Ideal Legal System for Attracting Foreign Direct Investment? Some Theory and Reality. American University International Law Review, Volume 15, Issue 6, Article 11 , 1627-1657.

Sahoo, D. P. Determinants of FDI in South Asia. Delhi: Institute of Economic Growth, Delhi University.

STEIN, C. D. (November 2007). The quality of institutions and Foreign Direct Investment . Economics and Politics Volume 19 , 317-344 DOI: 10.1111/j.1468-0343.2007.00318.x.

UN Economic and Social Commission for Asia and the Pacific. (2019). Foreign Direct Investment Trends and Outlook in Asia and the Pacific. Bangkok, Thailand: UN ESCAF Secretariat.

Voigt, L. P. (n.d.). Judicial Independence and Economic Growth:Some Proposal regarding Judiciary. 285-335.

Voigt, S. (2008). The economic effects of judicial accountability: cross-country evidence. European Journal of Law and Economics , DOI 10.1007/s 10657-007-9035-5.

Wee Kee Hwee,Karim Kirollos and Maria Cecilla Salta. (2018). ASEAN Investment Report . Jakarta 12110 Indonesia: The ASEAN Secretariat.

Yu, J. P. (July 2010). Determinants of Foreign Direct Investment: A Sectoral and Institutional Approach. IMF Working Paper, WP-10/187. 
Appendix A

\begin{tabular}{|c|c|c|}
\hline S1 & Country & CODE \\
\hline 1 & Bangladesh & BGD \\
\hline 2 & India & IND \\
\hline 3 & SriLanka & LKA \\
\hline 4 & Pakistan & NPL \\
\hline 5 & Nepal & BTN \\
\hline 6 & Bhutan & MDV \\
\hline 7 & Maldives & AFG \\
\hline 8 & Afganistan & VNM \\
\hline 9 & Vietnam & THA \\
\hline 10 & Thailand & PHL \\
\hline 11 & Philippines & MYS \\
\hline 12 & Malaysia & MMR \\
\hline 13 & Myanmar & LAO \\
\hline 14 & Lao & IDN \\
\hline 15 & Indonesia & KHR \\
\hline 16 & Cambodia & SGP \\
\hline 17 & Singapore & BRN \\
\hline 18 & Brunei DS & \\
\hline
\end{tabular}


Figures

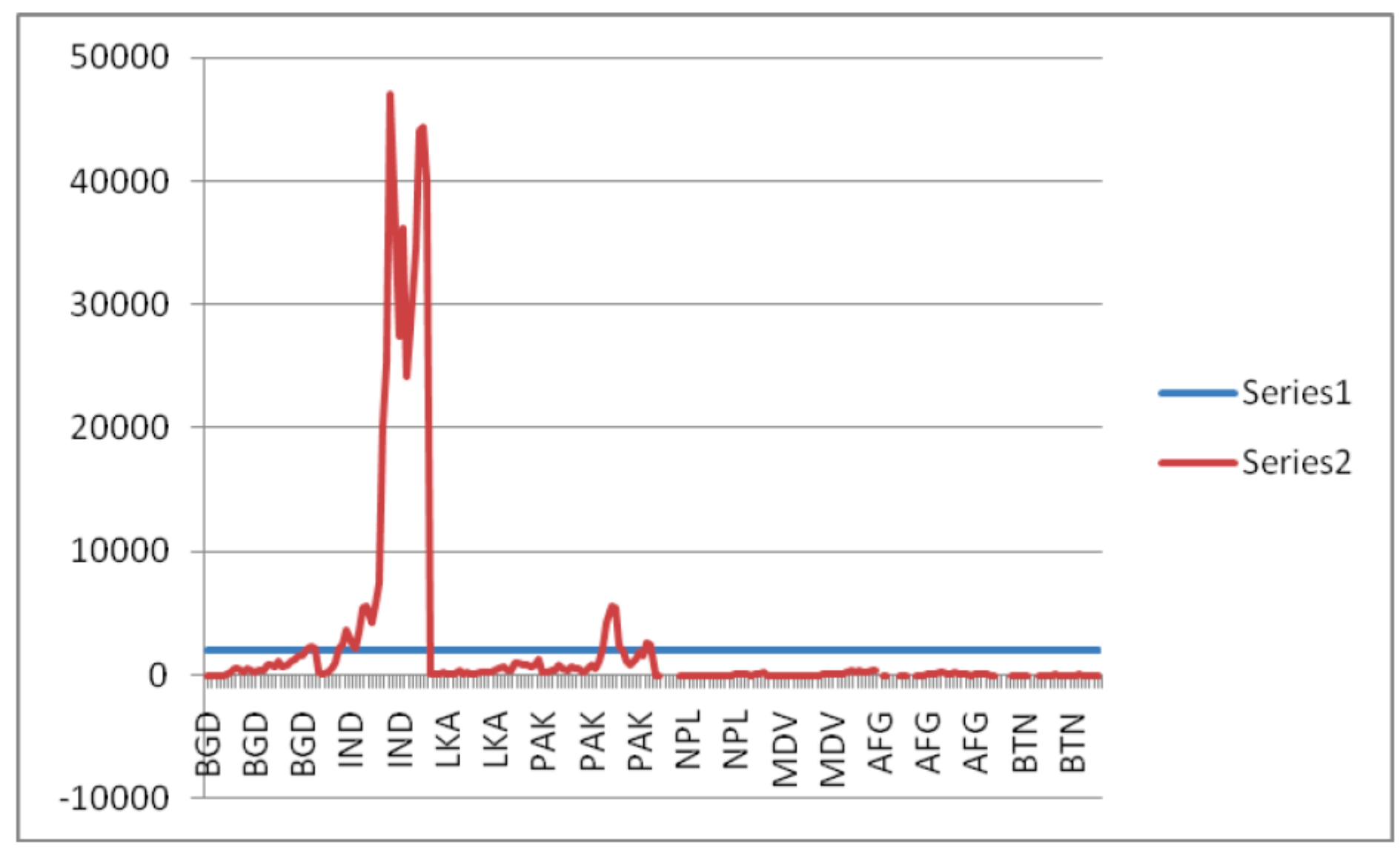

Figure 1

Trend of FDI in South Asia Region 


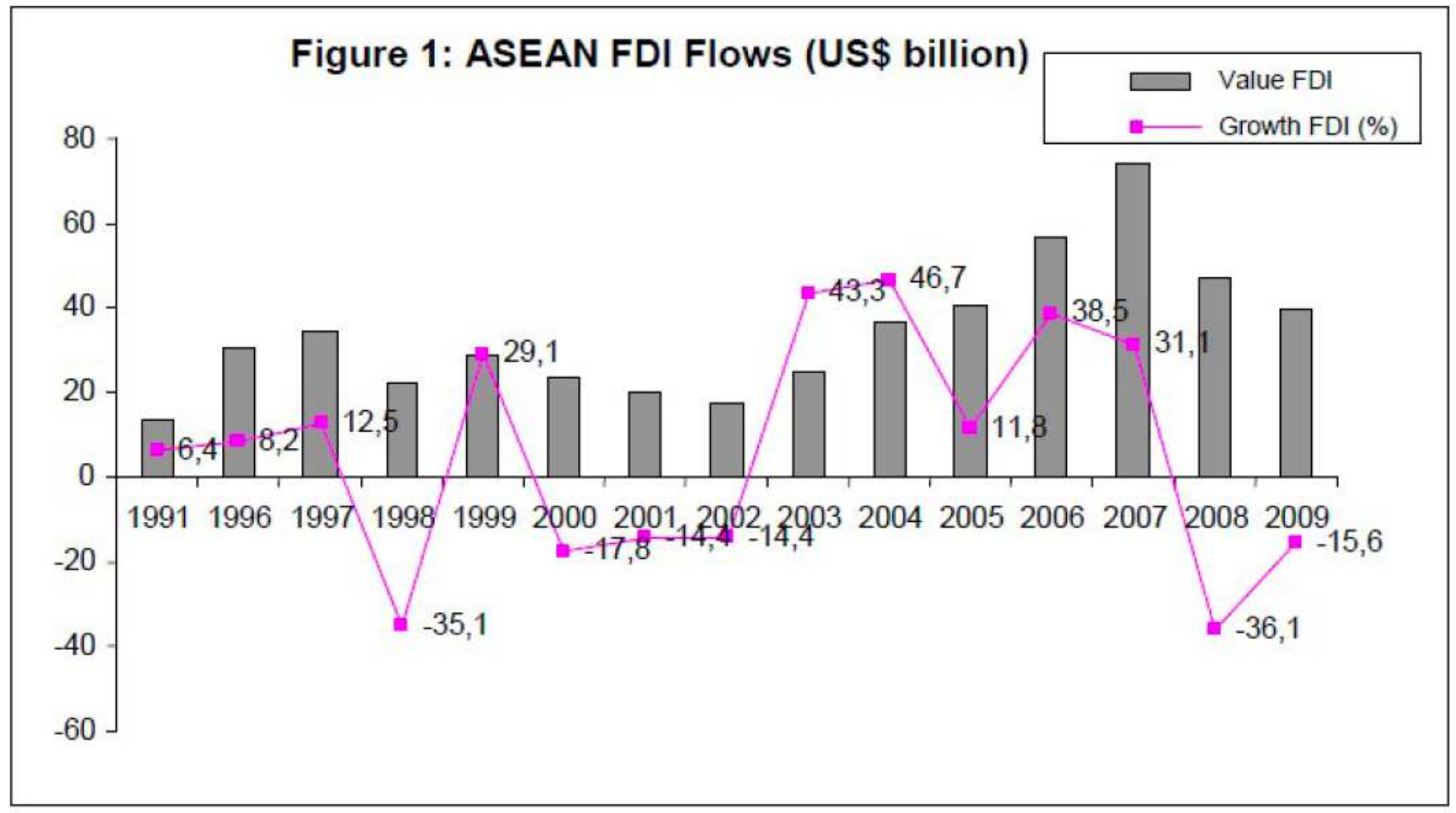

Source: UNCTAD Stat.

Figure 2

ASEAN FDI flows (US\$ billion) 


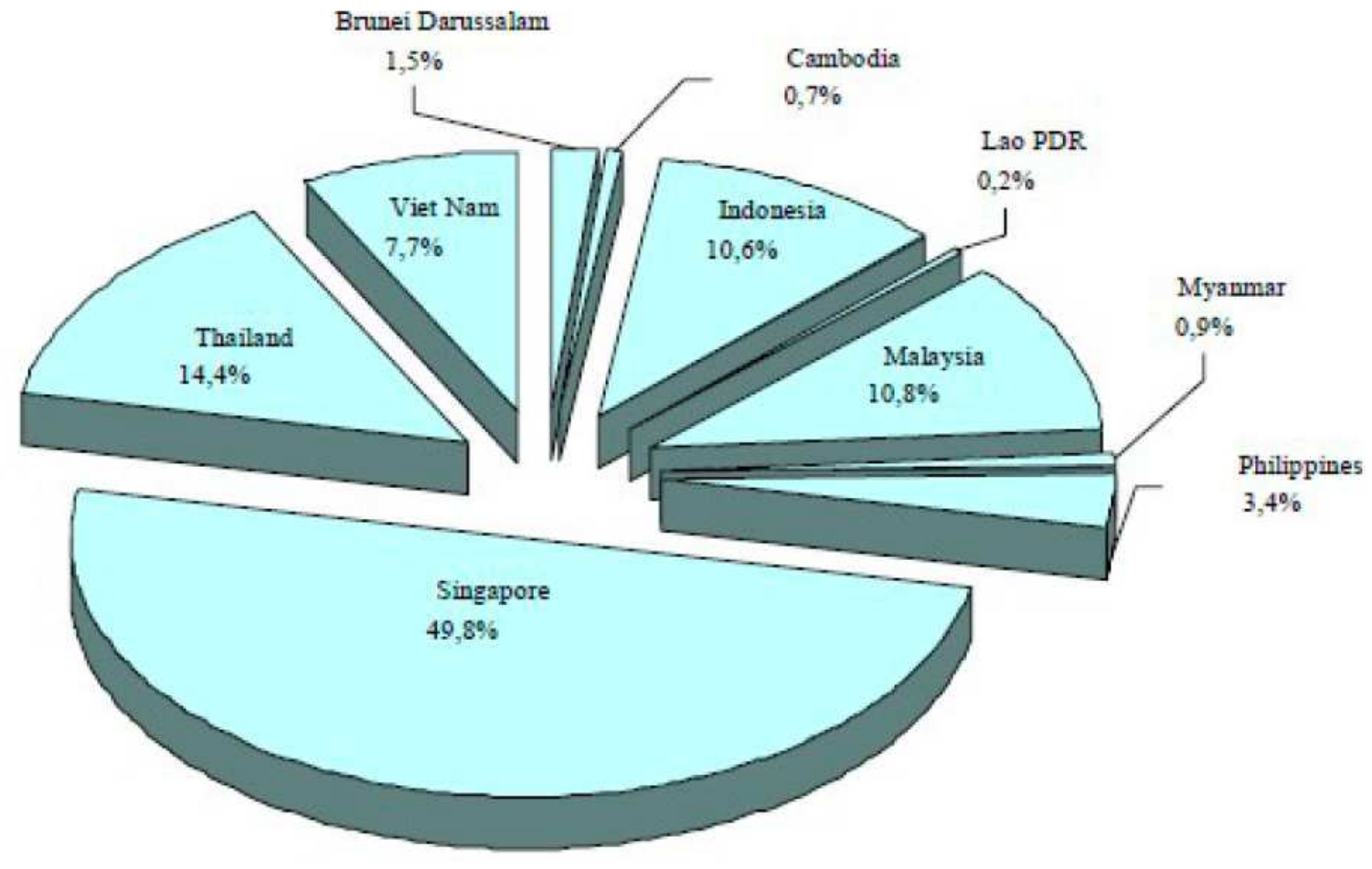

\section{Ref: UNCTAD}

Figure 3

Share of FDI among the Southeast Asian countries 


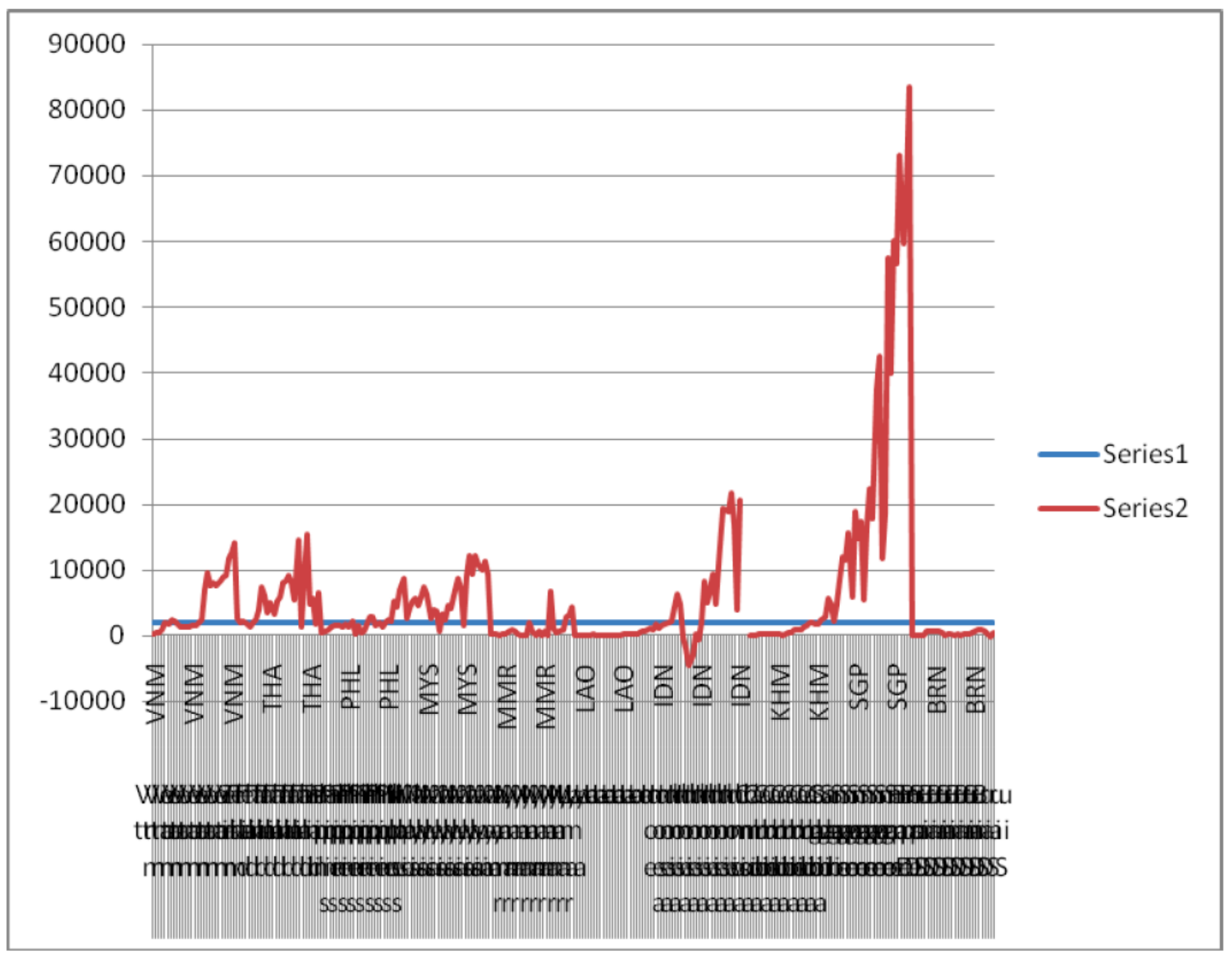

Figure 4

FDI inflow trend in South East Asia(1990-2017) 


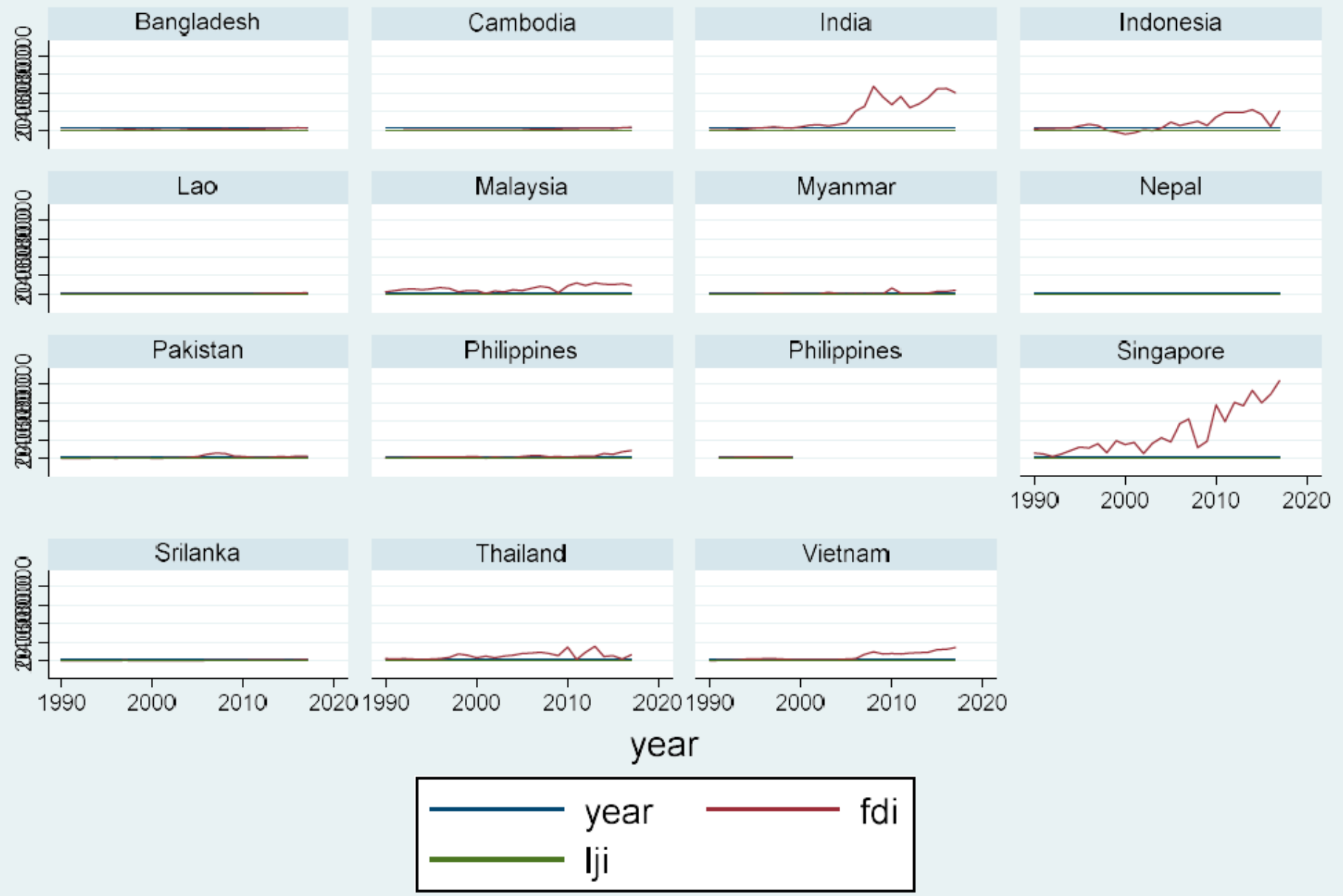

Graphs by country

Figure 5

FDI and $\mathrm{JI}$ in the South \& Southeast Asia 